\title{
Correction
}

\section{Correction to: Analysis of Changing Residential Fire Dynamics and Its Implications on Firefighter Operational Timeframes}

Stephen Kerber*, UL, LLC, 333 Pfingsten Rd., Northbrook, IL 60062, USA

\section{Correction to: Fire Technology (201 2) 48:865-891 https://doi.org/ 10.1007 /s $10694-01$ 1-0249-2}

The article Analysis of Changing Residential Fire Dynamics and Its Implications on Firefighter Operational Timeframes, written by Stephen Kerber, was originally published electronically on the publisher's internet portal (currently SpringerLink) on December 8, 2011, without open access.

With the author(s)' decision to opt for Open Choice the copyright of the article changed on September 20, 2019, to (c) The Author(s) 2019 and the article is forthwith distributed under the terms of the Creative Commons Attribution 4.0 International License (http://creativecommons.org/licenses/by/4.0/), which permits use, duplication, adaptation, distribution and reproduction in any medium or format, as long as you give appropriate credit to original author(s) and the source, provide a link to the Creative Commons license and indicate if changes were made.

Publisher's Note Springer Nature remains neutral with regard to jurisdictional claims in published maps and institutional affiliations.

* Correspondence should be addressed to: Stephen Kerber, E-mail: Stephen.kerber@us.ul.com The original article can be found online at https://doi.org/10.1007/s10694-011-0249-2. 